\title{
Comparison of the demographic and clinical features of pregnant and non-pregnant patients undergoing appendectomy
}

\author{
Cemalettin Koç, M.D., ${ }^{1}$ (ㄱ) Sami Akbulut, M.D., ${ }^{1}$ Ebru İnci Coşkun, M.D., ${ }^{2}$ \\ Barış Sarıcı, M.D., ${ }^{1}$ (i) Sezai Yılmaz, M.D.'
}

1'Department of Surgery and Liver Transplant Institute, İnönü University Faculty of Medicine, Malatya-Turkey

${ }^{2}$ Department of Obstetrics and Gynecology, Inönü University Faculty of Medicine, Malatya-Turkey

\begin{abstract}
BACKGROUND: This retrospective study aims to compare the demographic and clinicopathological characteristics of the pregnant and non-pregnant patients who underwent appendectomy with a presumed diagnosis of acute appendicitis.

METHODS: Between June 2009 and January 2019, 431 reproductive-aged of female patients underwent appendectomy with a presumed diagnosis of acute appendicitis. Patients were divided into two groups considering their pregnancy status: pregnant group ( $\mathrm{n}=48$ ) and non-pregnant group $(\mathrm{n}=383)$. Both groups were compared with respect to demographic, clinical and histopathological features.

RESULTS: No statistically significant difference was found between pregnant and non-pregnant groups except total bilirubin level $(p=0.019)$ and ultrasonographic findings $(p=0.016)$. In the non-pregnant group, negative appendectomy and perforation rates were $26 \%$ and $10.5 \%$, where these rates for the pregnant group were $20.8 \%$ and $4.2 \%$. Sensitivity, specificity and accuracy rates of ultrasonography for the pregnant group were $50 \%, 100 \%$ and $58.5 \%$, where these rates for the non-pregnant group were $67.3 \%, 57.9 \%$ and $65 \%$. The pregnancy date was the first trimester in $52.1 \%$, the second trimester in $29.2 \%$ and the third trimester in $16.7 \%$ of the pregnants. None of the term births (87.5\%) resulted in neither a fetal nor a maternal complication. However, $12.5 \%$ of the preterm births resulted in neonatal mortality.
\end{abstract}

CONCLUSION: Although not statistically significant, this study points out relatively lower rates of negative appendectomy and perforated acute appendicitis among pregnant patients, which is related to the overly attentive evaluation of pregnants admitted due to acute abdomen.

Keywords: Acute appendicitis; appendectomy; obstetric complications; pregnancy; preterm labour.

\section{INTRODUCTION}

Acute appendicitis (AAp) is among the leading causes of emergency unit admissions due to abdominal pain and appendectomy is among the world wide most performed surgical procedures. $^{[1,2]}$ Obstruction of appendix vermiformis lumen due to any cause triggers an inflammatory process that initially begins in epithelium progressing into serosa, resulting in classical sign and symptoms of AAp. ${ }^{[2]}$ Lifetime real AAp risk varies from $5 \%$ to $20 \%$ and which is around $6.9 \%$ for women..$^{[1,2]}$
AAp is one of the most frequent conditions of pregnant women requiring an emergent surgical procedure. AAp incidence during pregnancy varies from 1/800 to I//500 and has a relatively lower incidence compared with non-pregnant women of the same age. ${ }^{[3]}$ Loss of appetite, nausea, and vomiting, abdominal pain are the cardinal signs and symptoms of AAp, which are frequently common in the normal physiological course of pregnancy. ${ }^{[4]}$ Therefore, diagnosing AAp in a pregnant patient is challenging and $25 \%$ to $50 \%$ of patients are preoperatively underdiagnosed. ${ }^{[4]}$ Delay in diagnosis or

Cite this article as: Koç C, Akbulut S, Coşkun Eİ, Sarııı B, Yılmaz S. Comparison of the demographic and clinical features of pregnant and non-pregnant patients undergoing appendectomy. Ulus Travma Acil Cerrahi Derg 2020;26:555-562.

Address for correspondence: Cemalettin Koç, M.D.

İnönü Üniversitesi Tıp Fakültesi, Genel Cerrahi Anabilim Dalı, Malatya, Turkey

Tel: +90 422 - 34I 0660 E-mail: ckoc_4l@hotmail.com

Ulus Travma Acil Cerrahi Derg 2020;26(4):555-562 DOI: 10.14744/tjtes.2020.12544 Submitted: 19.09.2019 Accepted: 15.01.2020 Online: I5.06.2020

Copyright 2020 Turkish Association of Trauma and Emergency Surgery 
underdiagnosis in pregnant patients results in perforation and peritonitis, which leads to unfavorable complications of early delivery, miscarriage, fetal loss, and maternal mortality. ${ }^{[4]}$ This study presented aims, first of all, compare demographic, biochemical and histopathological features of pregnant and non-pregnant female patients admitted to our surgery clinic instruction with an initial diagnosis of AAp. The second aim is to present maternal and fetal complication following appendectomy among pregnant patients.

\section{MATERIALS AND METHODS}

Between June 2009 and January 2019, the demographic, biochemical and histopathological features of the 48 pregnant patients who underwent appendectomy with presumed diagnosis of AAp at Inonu University Faculty of Medicine, Department of Surgery were analyzed retrospectively. This group was defined as the Pregnant group $(n=48)$. A control group was created to compare with the pregnant group and this group was defined as non-pregnant group $(n=383)$. The nonpregnant group consists of reproductive-aged (range: 18-45 years) female patients who presented to our emergency unit with abdominal pain at the same time frame and underwent appendectomy with the presumed diagnosis of AAp. Patients' medical records were reviewed after obtaining approval from Inonu University institutional review board for non-interventional studies (Approval No:2019/4-4I). Both groups were compared in terms of age (years), white blood cell (WBC), Neutrophil, Lymphocyte, Platelets, mean corpuscular hemoglobin $(\mathrm{MCH})$, red cell distribution width (RDW), mean platelet volume (MPV), mean corpuscular volume (MCV), platelet distribution width (PDW), C-reactive protein (CRP), neutrophil to lymphocyte ratio (NLR), platelet to lymphocyte ratio (PLR), platelet to neutrophil ratio (PNR), white blood cell to lymphocyte ratio (WLR), white blood cell to neutrophil ratio (WNR) bilirubin, appendix width $(\mathrm{mm})$, appendix length $(\mathrm{mm})$ and histopathological findings.

Pregnancy is categorized into three phases of the first trimester (0-14 wk), second trimester (15-28 wk) and third trimester (29-42 wk). ${ }^{[5]}$ Patients younger than 18 years of age are excluded from this study. Therefore, non-pregnant patients from 18 to 45 years of age are included in the control group for matching the age of the pregnant group. All patients admitted to the emergency unit with an initial diagnosis of AAp were evaluated with routine anamnesis (such as date of last menstrual period, sexual activity), blood $\beta$-hCG level and abdominopelvic ultrasonography (US) to rule out obstetrical and gynecological conditions.

Demonstration of a non-compressible, aperistatltic tubular structure originating from cecum, with a blind end, anteroposterior diameter $>6 \mathrm{~mm}$ in US evaluation is defined as AAp. Additionally, thickened intestinal wall, inflammation, increased echogenicity of surrounding mesenteric fatty tissue, heterogeneity, appendicolith, presence of either pericecal or abdominal free fluid are considered of a diagnostic fact independent from the visual status of the appendix. Patients with a history of actual pregnancy status did not undergo a computerized tomography (CT) evaluation. Although magnetic resonance imaging $(\mathrm{MRI})$ is among the examination techniques for differential diagnosis of AAp in pregnant patients, none of the patients at our institution underwent an MRI procedure. Concerning macroscopic and microscopic findings, pathological examination reports are classified as appendix vermiformis (without any evidence for inflammatory cell infiltration), lymphoid hyperplasia and acute appendicitis (simple appendicitis, perforated appendicitis, gangrenous appendicitis, phlegmonous appendicitis). Rare entities of granulomatous appendicitis, fibrous obliteration, mucocele, mucinous cystadenoma and carcinoid tumor are also classified. Antibioprophylaxy is given to all patients in the two groups. Patients with intraoperative diagnosis of appendix perforation, presence of periappendicular or pelvic fluid resembling to be infected received antibiotic treatment postoperatively. Centers for Disease Control and Prevention Guideline were considered in the evaluation of postoperative surgical site infections.

\section{Specific Obstetric Assessment in Pre/Perioperative Period}

All patients with an initial diagnosis of AAp with a reproductive age were evaluated by an obstetrics and gynecology specialist. All of the pregnant patients underwent a vaginal examination to detect any ex utero haemorrhage, miscarriage material inside vagina or cervix. Pregnant patients in second and trimester were evaluated with the transvaginal US to measure cervical longitude and detect the presence of any cervical funneling. Pregnants in a suitable gestational week were evaluated with tocography to detect presence of uterine contraction and ultrasonographic foetal nonstress test to clarify the well-being of the foetus. Pregnants in the first trimester that are with a relatively higher risk for miscarriage received supplementary progesterone. Pregnants in the third trimester with uterine contractions pointing out increased risk for preterm delivery received tocolytic treatment and supplements to promote foetal pulmonary development. All of the pregnants received adequate perioperative hydration to prevent dehydration.

\section{Statistical Analysis}

The statistical analyses were performed using IBM SPSS Statistics v25.0 (Statistical Package for the Social Sciences, Inc, Chicago, IL, USA). The quantitative variables were expressed as Mean \pm SD, Median and Min-Max. The qualitative variables were reported as number and percentage (\%). Kolmogorov-Smirnov tests were used to assess normality distribution of quantitative variables. Mann-Whitney $U$ test was used to compare the quantitative variables. Pearson ChiSquare and Fisher's exact tests were used to compare qualitative variables. Sensitivity, specificity, positive predictive value, 
negative predictive value and accuracy value of ultrasonography in pregnant patients with presumed diagnosis of acute appendicitis were also measured. A p-value of less than 0.05 was considered statistically significant.

\section{RESULTS}

\section{Pregnant versus Non-pregnant Patients Undergoing Appendectomy}

A sum of 431 women in reproductive age varying from 18 to 45 underwent appendectomy with an initial diagnosis of AAp. Patients were grouped into two, according to their pregnancy status at the time of AAp diagnosis: pregnant group $(n=48)$ and non-pregnant group $(n=383)$. There was no statistically significant difference between the groups concerning age $(p=0.710)$, WBC $(p=0.956)$, neutrophil count $(p=0.868)$, lymphocyte count $(p=0.571)$, thrombocyte count $(p=0.0 .814)$, RDW $(p=0.066)$, PDW $(p=0.183)$, $\mathrm{MCH}(p=0.105), \operatorname{MPV}(p=0.773), M C V(p=0.775), C R P$ $(p=0363),. N L R(p=0.486), P L R(p=0.7 \mid 2), P N R(p=0.85 I)$, WLR $(p=0.430)$, WNR $(p=0.204)$, appendix length $(p=0.581)$, appendix width $(p=0.734)$, general histopathological findings $(p=0.580)$, appendiceal perforation $(p=0.204)$ and presence of histopathological AAp $(p=0.429)$. On the other hand, there was a statistically significant difference between the groups for total bilirubin level $(p=0.019)$ and diagnosis of AAp in US evaluation $(p=0.016)$. Median bilirubin level was $0.58 \mathrm{mg} / \mathrm{dL}$ (mean \pm SD: $0.7 I \pm 0.50$ ) in the non-pregnant group, whereas it was $0.49 \mathrm{mg} / \mathrm{dL}$ (mean $\pm \mathrm{SD}: 0.58 \pm 0.53$ ) in the pregnant group. US evaluation diagnosed AAp in $61 \%$ of 351 non-pregnant group, whereas this rate was $41.5 \%$ among 41 pregnant patients. Sensitivity, specificity, positive predictive value (PPV), negative predictive value (NPV) and accuracy rates for US in pregnants were $50.0 \%, 100.0 \%, 100.0 \%, 29.1 \%$ an $58.5 \%$ in order, AAp and appendiaecal perforations for non-pregnant patients were $74 \%$ and $10.5 \%$ in order which were $79.2 \%$ and $4.2 \%$ for pregnant patients. In other words, negative appendectomy rates for non-pregnant and pregnant patients were $26 \%$ and $20.8 \%$ in order. None of the cases resulted in a surgical site or organ infection requiring either relaparotomy or percutaneous drainage. Only two cases in each group had superficial surgical site infection requiring simple drainage. Demographic, clinical and histopathological features of the two groups are given in Table I, 2.

\section{Obstetric Course of Pregnant Patients Undergoing Appendectomy}

A total of 13.734 deliveries were conducted at our obstetrical department during same time frame and an incidence of one case of appendectomy for preliminary diagnosis of AAp in 286 births. Also, pregnant women consisted of $11.1 \%$ of the reproductive-aged women who underwent appendectomy due to preliminary diagnosis of AAp. Among the 48 pregnants who underwent appendectomy, $25(52.1 \%)$ pregnants were in first trimester, 14 (29.2\%) pregnants were in second trimester, remaining eight (16.7\%) pregnants were in the third trimester of pregnancy. Among the 23 of the patients in the first trimester and 10 of the patients in the second trimester, appendectomy was performed using McBurney incision. Remaining two patients in the first trimester underwent laparoscopic appendectomy. Ten the second trimester patients and all of the third trimester patients underwent appendectomy via Rockey-Davis or pararectal incision, considering dimensions of the uterus and locational change of cecum. Following appendectomy, 42 (87.5\%) of the pregnants gave vaginal birth, the remaining six $(12.5 \%)$ of the pregnants admitted to the obstetrics clinic due to preterm delivery (3-8 weeks before gestational term). Among the preterm delivery pregnants, five of them gave birth via caserian section; one pregnant gave vaginal birth.

Among the term deliveries, all of the babies were free of mortality and morbidity. Among the preterm delivery pregnants, one had diamniotic dichorionic twins and delivered two male babies on $28^{\text {th }}$ week with a body weight of $1800 \mathrm{gr}$ and $1900 \mathrm{gr}$. One of the preterm pregnants on 30th gestational week, the baby was delivered but died postpartum day 17 due to respiratory failure. Another preterm pregnancy on 22nd gestational week was terminated following the diagnosis of in-utero exitus of a $500 \mathrm{gr}$ foetus. Mean birth weight of babies was $2950 \mathrm{gr}$ (min-max:). As a result, 31 (64.6\%) pregnants underwent a casearian section, and 17 (35.4\%) delivered transvaginally.

\section{DISCUSSION}

AAp is among the most frequent non-obstetrical conditions requiring surgical treatment. Frequency of pregnant patient those diagnosed $A A p$ and underwent appendectomy varies from 0.18 to 10.56 per every 1000 pregnants. Our literature analysis of 67 published studies reveals that 11.198 of II.556.46I pregnants underwent surgical exploration with a preliminary diagnosis of A Ap. In other words, the frequency of appendectomy per 1000 pregnants is 0.97 (Table 3).

Acceptable negative appendectomy (NA) is among the most frequently emphasized issues, which has a reported rate vary from $0 \%$ to $50 \%$ in many studies. The general consensus for an acceptable NA rate is 10 to $25 \%$. However, newer studies report rates lower than $10 \%$ related to recent diagnostic instrumentation and scoring systems. ${ }^{[6-8]}$ As Tubo-ovarian diseases are leading conditions resembling AAp, the NA rate is higher in female patients than in males. Literature review of the 14 published studies $(n=98.933)$ comparing pregnant $(n=3.97 \mathrm{I})$ and non-pregnant AAp $(n=94.962)$ reveal that NA rates of pregnant women vary from $0 \%$ to $38 \%$ whereas NA rates of non-pregnant women vary from $0 \%$ to $21.8 \%$. [4,5,9-20] In eight of these studies, NA was found to be higher in pregnant patients, whereas in three of these studies, NA was found to be higher in non-pregnant. Although it was not statistically significant, NA rates of pregnants were higher in 
Table I. Comparison of the pregnant and non-pregnant Acute appendicitis patients concerning clinical, biochemical and histopathological parameters

\begin{tabular}{|c|c|c|c|}
\hline \multirow[t]{2}{*}{ Patients' characteristics } & \multirow{2}{*}{$\frac{\text { Non-pregnant }(\mathrm{n}=383)}{\text { Median }(\min -\max )}$} & \multirow{2}{*}{$\frac{\text { Pregnant }(n=48)}{\text { Median }(\min -\max )}$} & \multirow[t]{2}{*}{$\mathbf{p}$} \\
\hline & & & \\
\hline Age & $28(18-45)$ & $27.5(19-45)$ & 0.710 \\
\hline White blood cell & $12.4(1.2-26.9)$ & $12.4(6.3-22.4)$ & 0.956 \\
\hline Neutrophil & $9.7(0.4-22.9)$ & $9.6(2.4-30.8)$ & 0.868 \\
\hline Lymphocyte & I.6 (0.2-7.8) & $1.7(0.5-14.8)$ & 0.571 \\
\hline Platelets & $251(43-570)$ & $246(14 \mid-573)$ & 0.814 \\
\hline Red cell distribution width & |3.7 (1 |-33.3) & $14.5(\mid 1.9-24.2)$ & 0.066 \\
\hline Platelet distribution width & $16.2(8.4-23.9)$ & $16.5(9.6-19.1)$ & 0.183 \\
\hline Mean corpuscular hemoglobin & $28.5(\mid 4.5-36.9)$ & $29(20.9-32.7)$ & 0.105 \\
\hline Mean platelet volume & $9(6.1-14.5)$ & $8.9(5.4-12.7)$ & 0.773 \\
\hline Mean corpuscular volume & $84.6(56-108)$ & $84.9(66-93)$ & 0.775 \\
\hline Total bilirubin & $0.58(0.13-3.66)$ & $0.49(0.19-3.48)$ & 0.019 \\
\hline C-reactive protein & $\mathrm{I} .86(0.1-55)$ & $2.26(0.3-35.2)$ & 0.363 \\
\hline Neutrophil to lymphocyte ratio & $5.6(0.15-4 \mid .2)$ & $5.8(1.7-30.8)$ & 0.486 \\
\hline platelet to lymphocyte ratio & $155(22-1065)$ & $150(66-955)$ & 0.712 \\
\hline Platelet to neutrophil ratio & $25.4(7.1-382)$ & $25.3(7.1-100)$ & 0.851 \\
\hline White blood cell to lymphocyte ratio & $7.1(1.15-46.7)$ & $7.5(1.1-32.2)$ & 0.430 \\
\hline white blood cell to neutrophil ratio & $1.3(0.5-14.2)$ & $1.2(0.5-6.9)$ & 0.204 \\
\hline Appendix lenght (mm) & $60(10-120)$ & $60(30-130)$ & 0.581 \\
\hline \multirow[t]{2}{*}{ Appendix width (mm) } & $10(5-60)$ & $10(4-30)$ & 0.734 \\
\hline & n (\%) & n (\%) & \\
\hline Ultrasonography & & & 0.016 \\
\hline Acute appendicitis (-) & $137(39)$ & $24(58.5)$ & \\
\hline Acute appendicitis (+) & $214(6 I)$ & $17(4 \mid .5)$ & \\
\hline Appendectomy type & & & 0.001 \\
\hline Open & $295(77)$ & $46(95.8)$ & \\
\hline Lap & $88(23)$ & $2(4.2)$ & \\
\hline Histopathological findings & & & 0.580 \\
\hline Appendix vermiformis & 35 & 4 & \\
\hline Acute appendicitis & 237 & 35 & \\
\hline Perforated acute appendicitis & 40 & 2 & \\
\hline Lymphoid hyperplasia & 47 & 3 & \\
\hline Carcinoid & 2 & 1 & \\
\hline Mucocele & 2 & 1 & \\
\hline Granulomatous appendicitis & 2 & 0 & \\
\hline Fibrous obliteration & 16 & 2 & \\
\hline E. Vermiculairs & 2 & 0 & \\
\hline Appendiceal perforation & & & 0.204 \\
\hline Yes & $40(10.5)$ & $2(4.2)$ & \\
\hline No & $343(89.5)$ & $46(95.8)$ & \\
\hline Acute appendicitis & & & 0.429 \\
\hline Yes & $283(74)$ & $38(79.2)$ & \\
\hline No & $100(26)$ & $10(20.8)$ & \\
\hline
\end{tabular}


Table 2. Comparison of the ultrasonographic assessment of pregnant and non-pregnant patients

\begin{tabular}{|c|c|c|c|c|}
\hline & \multicolumn{2}{|c|}{ Pregnant $(n=4 I)$} & \multicolumn{2}{|c|}{ Non- pregnant $(n=35 I)$} \\
\hline & $\begin{array}{c}\text { Acute } \\
\text { appendicitis (+) }\end{array}$ & $\begin{array}{c}\text { Acute } \\
\text { appendicitis (-) }\end{array}$ & $\begin{array}{c}\text { Acute } \\
\text { appendicitis (+) }\end{array}$ & $\begin{array}{c}\text { Acute } \\
\text { appendicitis (-) }\end{array}$ \\
\hline Ultrasonography acute appendicitis (+) & 17 & 0 & 177 & 37 \\
\hline Ultrasonography acute appendicitis (-) & 17 & 7 & 86 & 51 \\
\hline Sensitivity & \multicolumn{2}{|c|}{$50.0 \%$} & \multicolumn{2}{|c|}{$67.3 \%$} \\
\hline Specificity & \multicolumn{2}{|c|}{$100 \%$} & \multicolumn{2}{|c|}{$57.9 \%$} \\
\hline Positive predictive value & \multicolumn{2}{|c|}{$100 \%$} & \multicolumn{2}{|c|}{$82.7 \%$} \\
\hline Negative predictive value & \multicolumn{2}{|c|}{$29.2 \%$} & \multicolumn{2}{|c|}{$37.2 \%$} \\
\hline Accuracy & \multicolumn{2}{|c|}{$58.5 \%$} & \multicolumn{2}{|c|}{$65.0 \%$} \\
\hline
\end{tabular}

Table 3. Literature review of some studies published in English language literature on ratio of the pregnant acute appendicitis

\begin{tabular}{|c|c|c|c|c|}
\hline References & Journal & $\begin{array}{l}\text { Total delivery } \\
\text { or pregnancy }\end{array}$ & $\begin{array}{l}\text { Pregnant } \\
\text { appendicitis }\end{array}$ & $\begin{array}{c}\text { Pregnant appendicitis/ } \\
\text { Delivery }(1000)\end{array}$ \\
\hline Aras & Rev Assoc Med Bras (1992). 2016;62:622-7 & 6.540 & 38 & 5.81 \\
\hline Masood & Obstet Gynecol Int J 2016;5: 00173 & 12.687 & 134 & 10.56 \\
\hline Aggenbach & Int J Surg. 2015;15:84-9 & 25.443 & 21 & 0.83 \\
\hline Cheng & Surg Endosc. 2015;29:1394-9 & 1.147 .214 & 859 & 0.75 \\
\hline Kumamoto & Surg Today. 2015;45:1521-6 & 13.479 & 33 & 2.45 \\
\hline Abbasi & BJOG. 20I4;121:1509-14 & 7.037 .386 & 7114 & 1.01 \\
\hline Al- Dahamsh & J College of Med Sci-Nepal 20I2; 8: 36-43 & 9.783 & 28 & 2.86 \\
\hline Jung & J Korean Soc Coloproctol 2012;28:152-9 & 14.203 & 25 & 1.76 \\
\hline Agholor & J Obstet Gynaecol Res. 201 I;37:1540-8 & 16.173 & 23 & 1.42 \\
\hline Park & Eur J Obstet Gynecol Reprod Biol. 2010 ;148:44 & 954 & 8 & 8.39 \\
\hline Freeland & Am J Surg. 2009;198:753-8 & 65.000 & 23 & 0.35 \\
\hline Kazim & Int J Surg. 2009;7:365-7 & 43.134 & 37 & 0.86 \\
\hline Machado & JSLS. 2009; 1 3:384-90 & 16.803 & 26 & 1.55 \\
\hline Zhang & Chin Med J (Engl). 2009; | 22:52।-4 & 30.098 & 102 & 3.39 \\
\hline Al-Mulhim & Saudi J Gastroenterol. 2008; 14: I I4-7 & 67.990 & 65 & 0.96 \\
\hline Moreno-Sanz & J Am Coll Surg. 2007;205:37-42 & 3.969 & 9 & 2.27 \\
\hline Rollins & Surg Endosc. 2004;|8:237-4| & 18.590 & 30 & 1.61 \\
\hline Ueberrueck & World J Surg. 2004;28:508-I I & 46.969 & 94 & 2.00 \\
\hline Raja & Rawal Med J 2003;28:52-5 & 3.812 & 11 & 2.89 \\
\hline Eryilmaz & Dig Surg 2002; 19:40-4 & 31.480 & 24 & 0.76 \\
\hline Popkin & Am J Surg 2002; 183: 20-2. & 36.000 & 23 & 0.64 \\
\hline Duqoum & East Mediterr Health J. $2001 ; 7: 642-5$ & 16.443 & 10 & 0.61 \\
\hline De Perrot & Surg Laparosc Endosc Percutan Tech.2000;10:368 & 3.702 & 9 & 2.43 \\
\hline Hoshino & Int J Gynaecol Obstet. 2000;69:27I-3 & 15.000 & 15 & 1.00 \\
\hline Mourad & Am J Obstet Gynecol. 2000;182:1027-9 & 66.993 & 67 & 1.00 \\
\hline Tracey & Am Surg. 2000;66:555-9 & 44.845 & 22 & 0.49 \\
\hline Affleck & Am J Surg. 1999;178:523-9 & 32.818 & 40 & 1.22 \\
\hline Al-Qudah & J Obstet Gynaecol. 1999;19:362-4 & 52.108 & 46 & 0.88 \\
\hline Andersen & Acta Obstet Gynecol Scand. 1999;78:758-62 & 32.163 & 56 & 1.74 \\
\hline
\end{tabular}


Table 3. Literature review of some studies published in English language literature on ratio of the pregnant acute appendicitis (continued)

\begin{tabular}{|c|c|c|c|c|}
\hline References & Journal & $\begin{array}{l}\text { Total delivery } \\
\text { or pregnancy }\end{array}$ & $\begin{array}{l}\text { Pregnant } \\
\text { appendicitis }\end{array}$ & $\begin{array}{l}\text { Pregnant appendicitis/ } \\
\text { Delivery }(1000)\end{array}$ \\
\hline Hee & Int J Gynaecol Obstet. 1999;65:129-35 & 320.949 & 117 & 0.36 \\
\hline Wittich & Mil Med. 1999;164:67|-4 & 6.050 & 6 & 0.99 \\
\hline Al-Mulhim & Int Surg. 1996;81:295-7 & 31.950 & 52 & 1.63 \\
\hline To & Aust N Z J Surg. 1995;65:799-803 & 38.070 & 38 & 1.00 \\
\hline Lopez & J Obstetrics Gynecol 1994; 14: 133-7 & 41.206 & 62 & 1.50 \\
\hline Halvorsen & Eur J Surg. 1992;158:603-6. & 44.577 & 16 & 0.36 \\
\hline Mahmoodian & South Med J. 1992;85:19-24 & 12.349 & 9 & 0.73 \\
\hline Al-Qasabi & Ann Saudi Med. 199|; | 1:58-61 & 31.245 & 46 & 1.47 \\
\hline Mazze & Obstet Gynecol. 1991;77:835-40 & 720.000 & 778 & 1.08 \\
\hline Tamir & Am J Surg. 1990;160:57I-5 & 73.000 & 84 & 1.15 \\
\hline Bailey & Am Surg. 1986;52(4):218-21 & 100.145 & 41 & 0.41 \\
\hline Horowitz & Arch Surg. 1985;120:1362-7 & 66.351 & 12 & 0.18 \\
\hline Weingold & Clin Obstet Gynecol. 1983;26:80I-9 & 19.187 & 24 & 1.25 \\
\hline Farquharson & Scott Med J. 1980;25:36-8 & 50.089 & 25 & 0.50 \\
\hline Punnonen & Acta Chir Scand. 1979;145:555-8 & 20.363 & 24 & 1.18 \\
\hline Gomez & Am J Surg. 1979;137:180-3 & 76.580 & 35 & 0.46 \\
\hline Babaknia & Obstet Gynecol. 1977;50:40-4 & 25.847 & 12 & 0.46 \\
\hline Zaitoon & Am Surg. 1977;43:395-8 & 11.844 & II & 0.93 \\
\hline Cunningham & Obstet Gynecol. 1975;45:4I5-20 & 91.800 & 34 & 0.37 \\
\hline Mohammed & Can Med Assoc J. 1975; I I2: I I87-8 & 34.270 & 25 & 0.73 \\
\hline Finch & Br J Surg. 1974;61:129-32 & 94.000 & 75 & 0.80 \\
\hline Taylor & N Z J Obstet Gynaecol. 1972;12:202-3 & 38.719 & 55 & 1.42 \\
\hline O’Neill & Aust N Z J Obstet Gynaecol. 1969;9:94-9 & 91.500 & 62 & 0.68 \\
\hline Kurtz & Obstet Gynecol 1964; 23(4):528-532 & 84.260 & 41 & 0.49 \\
\hline Sarason & Obstet Gynecol. 1963;22:382-6 & 11.000 & 14 & 1.27 \\
\hline Bronstein & Am J Obstet Gynecol. 1963;86:5।4-6 & 39.000 & 20 & 0.51 \\
\hline King & Calif Med. 1962;97:158-62 & 74.000 & 36 & 0.49 \\
\hline Lee & JAMA. 1965;193:966-8 & 16.100 & 34 & 2.11 \\
\hline MacBeth & Can J Surg. 1961;4:419-28 & 59.758 & 50 & 0.84 \\
\hline Townsend & Am Surg. 1960;26:425-7 & 33.000 & 29 & 0.88 \\
\hline West & Am Surg. 1960;26:425-7 & 39.867 & 35 & 0.88 \\
\hline Sprong & Calif Med. 1959;91:258-60 & 19.932 & 20 & 1.00 \\
\hline Easton & Postgrad Med J. 1957;33:272-7 & 8.608 & 14 & 1.63 \\
\hline Hoffman & Am J Obstet Gynecol. 1954;67:1338-50 & 44.242 & 126 & 2.85 \\
\hline Meharg & Obstet Gynecol. 1953;1:460-5 & 6.106 & 25 & 4.09 \\
\hline Priddle & Am J Obstet Gynecol. 1951;62:150-5 & 59.403 & 51 & 0.86 \\
\hline Hamlin & N Engl J Med. |950;244:|28-3| & 92.772 & 40 & 0.43 \\
\hline Baer & JAMA. 1932;98:1359-64 & 16.543 & 28 & 1.69 \\
\hline Total & II.543.752 & 11.198 & & 0.97 \\
\hline
\end{tabular}

the study we present ( 26.0 vs. $20.8 \%$ ). These results point out that higher NA rates demonstrate easier made surgical treatment decisions of surgeons to avoid AAp related com- plications, such as perforation, whereas lower NA rates of pregnants demonstrate meticulously made surgical treatment decisions of surgeons or use diagnostic tools more often. 
One of the subjects that AAp studies touch upon is the frequency of perforated AAp. This condition is the most important subject to be mentioned in these studies when its complications are considered. Some authors justify the relative favor between NA and complicated AAp, considering maternal and fetal complications and promote surgical treatment in all pregnants with a possibility of AAp. ${ }^{[20]}$ Opponent authors emphasize the $4 \%$ rate of maternal and fetal complications among pregnants who underwent NA and be in relief against considering NA as an innocent procedure. ${ }^{[20,21]}$ According to the literature analysis mentioned above, perforated AAp rates vary from $0 \%$ to $40.4 \%$ in pregnants and $3.7 \%$ to $29 \%$ in non-pregnants. Perforated AAp rate was high among pregnants in seven of these studies and was high among non-pregnants in three of these studies. These results reveal relatively high rates of both NA and perforated AAP among pregnants. In our study none of the pregnants that underwent NA experienced neither maternal nor fetal complication. On the contrary, one of the pregnants with a perforated AAP had an uncomplicated preterm delivery.

Many studies compare histopathologically proven AAp and non-AAP patient groups (control groups) to reveal sensitivity, specificity and cut-off levels of biochemical laboratory parameters (WBC, MPV, RDW, PDW, Platelets, Neutrophil, CRP, Bilirubin) in diagnosis and predicting of AAp related complications. ${ }^{[22,23]}$ Similar parameters are analyzed in pregnant AAp studies as well. ${ }^{[24]}$ However, a limited number of studies comparing pregnant and non-pregnant AAp patients analyse WBC and neutrophil counts, some of which reveal higher WBC or neutrophil counts in pregnant AAp group and some of them have non-significant difference. ${ }^{[4, I, I I-15]}$ One of the most important features of the study presented is comparing the groups concerning all the parameters mentioned above and revealing an insignificant difference between the groups except the total bilirubin levels.

Bilirubin is one of the most analyzed parameters in studies about AAp. Bacteria's hepatic involvement via portal vein following proliferation inside appendix lumen leading to the limitation in hepatic uptake and excretion and cytokine-mediated inhibition of bile salt transport have been shown previously. [24-28] Besides, hemolysis related to systemic infection has also been shown to result in an increase of bilirubin load. Many studies show a relatively higher increase in total bilirubin levels in complicated and uncomplicated AAp cases when compared with NA and the highest increase in complicated AAp. [24-28] However, some studies report a relatively increased bilirubin level among AAp group without any significant difference between complicated and non-complicated AAp groups. ${ }^{[28]}$ Bilirubin level has also been shown to be predicting factor for perforation and other complications related to AAp. To our knowledge, none of the pregnant AAp studies analyzed the relation between bilirubin level and AAp. This study reveals relatively higher levels of bilirubin in the non-pregnant AAp group compared with the pregnant AAp group. Besides, the comparison of histologically-proven AAp cases revealed relatively higher bilirubin levels in the non-pregnant group. Currently, we have no comment to clarify relatively lower bilirubin levels in the pregnant group and this study requires to be supported with further prospective studies.

We would like to share some exceptional facts of this study. First of all, non-pregnant appendectomised female patients in reproductive age were completely included in the control group to minimize the risk of bias. Secondly, the relatively lower sensitivity of US examination depends on the radiology residents on night-shift who are relatively less experienced. The third fact is the absence of an MR examination on any of the pregnants, as the MR examination and a radiology specialist were unavailable during night-shifts. The fourth is the difficulty in providing all of the patients' Alvarado scores admitted in the emergency unit of our institution despite most of the patients with a preliminary AAp diagnosis are followed with this score.

As a result, AAp is among the most frequent conditions requiring surgical treatment during pregnancy. Physiological changes of pregnants may interfere with clinical findings and biochemical parameters which leads to higher rates of perforated $A A p$ among pregnant $A A p$ patients. All patients with a preliminary diagnosis of AAp must be followed closely and evaluated with consecutive US examinations to minimize maternal and fetal complications.

Ethics Committee Approval: Approved by the local ethics committee.

Peer-review: Internally peer-reviewed.

Authorship Contributions: Concept: S.A.; Design: S.A., C.K.; Supervision: S.A., S.Y.; Fundings: C.K., B.S.; Materials: C.K., B.S., E.I.C.; Data: C.K., B.S., E.I.C.; Analysis: S.A.; Literature search: S.A., C.K.; Writing: S.A.; Critical revision: S.A., C.K., S.Y.

Conflict of Interest: None declared.

Financial Disclosure: The authors declared that this study has received no financial support.

\section{REFERENCES}

1. Akbulut S, Koc C, Kocaaslan H, Gonultas F, Samdanci E, Yologlu S, et al. Comparison of clinical and histopathological features of patients who underwent incidental or emergency appendectomy. World J Gastrointest Surg 2019;11:19-26. [CrossRef]

2. Emre A, Akbulut S, Bozdag Z, Yilmaz M, Kanlioz M, Emre R, et al. Routine histopathologic examination of appendectomy specimens: retrospective analysis of 1255 patients. Int Surg 2013;98:354-62. [CrossRef]

3. Andersson RE, Lambe M. Incidence of appendicitis during pregnancy. Int J Epidemiol 2001;30:1281-5. [CrossRef]

4. Aras A, Karaman E, Pekșen Ç, Kızıltan R, Kotan MÇ. The diagnosis of acute appendicitis in pregnant versus non-pregnant women: A comparative study. Rev Assoc Med Bras (1992) 2016;62:622-7. [CrossRef]

5. Ito $\mathrm{K}$, Ito $\mathrm{H}$, Whang $\mathrm{EE}$, Tavakkolizadeh $\mathrm{A}$. Appendectomy in pregnancy: evaluation of the risks of a negative appendectomy. Am J Surg 
2012;203:145-50. [CrossRef]

6. Kapan S, Bozkurt MA, Turhan AN, Gönenç M, Alış H. Management of acute appendicitis in pregnancy. Ulus Travma Acil Cerrahi Derg 2013;19:20-4. [CrossRef]

7. Sammalkorpi HE, Mentula P, Savolainen H, Leppäniemi A. The Introduction of Adult Appendicitis Score Reduced Negative Appendectomy Rate. Scand J Surg 2017;106:196-201. [CrossRef]

8. Schok T, Simons PC, Janssen-Heijnen ML, Peters NA, Konsten JL. Prospective evaluation of the added value of imaging within the Dutch National Diagnostic Appendicitis Guideline--do we forget our clinical eye?. Dig Surg 2014;31:436-43. [CrossRef]

9. Segev L, Segev Y, Rayman S, Nissan A, Sadot E. Acute Appendicitis During Pregnancy: Different from the Nonpregnant State?. World J Surg 2017;41:75-81. [CrossRef]

10. Davoodabadi A, Davoodabadi H, Akbari H, Janzamini M. Appendicitis in Pregnancy: Presentation, Management and Complications. Zahedan J Res Med Sci 2016;18:e7557. [CrossRef]

11. Baruch Y, Canetti M, Blecher Y, Yogev Y, Grisaru D, Michaan N. The diagnostic accuracy of ultrasound in the diagnosis of acute appendicitis in pregnancy.J Matern Fetal Neonatal Med 2019;1-6. [CrossRef]

12. Bazdar S, Dehghankhalili M, Yaghmaei S, Azadegan M, Pourdavood A, Niakan MH, et al. Acute Appendicitis during Pregnancy; Results of a Cohort Study in a Single Iranian Center. Bull Emerg Trauma 2018;6:122-7. [CrossRef]

13. Bhandari TR, Shahi S, Acharya S. Acute Appendicitis in Pregnancy and the Developing World. Int Sch Res Notices 2017;2017:2636759. [CrossRef]

14. Tatli F, Yucel Y, Gozeneli O, Dirican A, Uzunkoy A, Yalçın HC, et al. The Alvarado Score is accurate in pregnancy: a retrospective case-control study. Eur J Trauma Emerg Surg 2019;45:411-6. [CrossRef]

15. Kumamoto K, Imaizumi H, Hokama N, Ishiguro T, Ishibashi K, Baba $\mathrm{K}$, et al. Recent trend of acute appendicitis during pregnancy. Surg Today 2015;45:1521-6. [CrossRef]

16. McGory ML, Zingmond DS, Tillou A, Hiatt JR, Ko CY, Cryer HM. Negative appendectomy in pregnant women is associated with a substan- tial risk of fetal loss. J Am Coll Surg 2007;205:534-40. [CrossRef]

17. Yilmaz HG, Akgun Y, Bac B, Celik Y. Acute appendicitis in pregnancy-risk factors associated with principal outcomes: a case control study. Int J Surg 2007;5:192-7. [CrossRef]

18. Finch DR, Lee E. Acute appendicitis complicating pregnancy in the $\mathrm{Ox}$ ford region. Br J Surg 1974;61:129-32. [CrossRef]

19. Richards C, Daya S. Diagnosis of acute appendicitis in pregnancy. Can J Surg 1989;32:358-60.

20. Hiersch L, Yogev Y, Ashwal E, From A, Ben-Haroush A, Peled Y. The impact of pregnancy on the accuracy and delay in diagnosis of acute appendicitis. J Matern Fetal Neonatal Med 2014;27:1357-60. [CrossRef]

21. Jung JY, Na JU, Han SK, Choi PC, Lee JH, Shin DH. Differential diagnoses of magnetic resonance imaging for suspected acute appendicitis in pregnant patients. World J Emerg Med 2018;9:26-32. [CrossRef]

22. Boshnak N, Boshnaq M, Elgohary H. Evaluation of Platelet Indices and Red Cell Distribution Width as New Biomarkers for the Diagnosis of Acute Appendicitis. J Invest Surg 2018;31:121-9. [CrossRef]

23. Ulukent SC, Sarici IS, Ulutas K. All CBC parameters in diagnosis of acute appendicitis. Int J Clin Exp Med 2016;9:11871-6.

24. Çınar H, Aygün A, Derebey M, Tarım İA, Akalın Ç, Büyükakıncak S, et al. Significance of hemogram on diagnosis of acute appendicitis during pregnancy. Ulus Travma Acil Cerrahi Derg 2018;24:423-8. [CrossRef]

25. Eren T, Tombalak E, Ozemir IA, Leblebici M, Ziyade S, Ekinci O, et al. Hyperbilirubinemia as a predictive factor in acute appendicitis. Eur J Trauma Emerg Surg 2016;42:471-6. [CrossRef]

26. D'Souza N, Karim D, Sunthareswaran R. Bilirubin; a diagnostic marker for appendicitis. Int J Surg 2013;11:1114-7. [CrossRef]

27. Nevler A, Berger Y, Rabinovitz A, Zmora O, Shabtai M, Rosin D, et al. Diagnostic Value of Serum Bilirubin and Liver Enzyme Levels in Acute Appendicitis. Isr Med Assoc J 2018;20:176-81.

28. Sushruth S, Vijayakumar C, Srinivasan K, Raj Kumar N, Balasubramaniyan G, Verma SK, et al. Role of C-Reactive Protein, White Blood Cell Counts, Bilirubin Levels, and Imaging in the Diagnosis of Acute Appendicitis as a Cause of Right Iliac Fossa Pain. Cureus 2018;10:e2070.

\section{ORİIINAL ÇALIŞMA - ÖZET}

\section{Apendektomi yapılan gebe ve gebe olmayan hastaların demografik ve klinik özelliklerinin karşılaştırılması}

\section{Dr. Cemalettin Koç, ${ }^{1}$ Dr. Sami Akbulut, ${ }^{1}$ Dr. Ebru İnci Coşkun, ${ }^{2}$ Dr. Barış Sarıcı, ${ }^{1}$ Dr. Sezai Yılmaz ${ }^{1}$}

${ }^{1}$ Inönü Üniversitesi Tıp Fakültesi, Cerrahi ve Karaciğer Nakli Enstitüsü, Malatya

2İnönü Üniversitesi Tıp Fakültesi, Kadın Hastalıkları ve Doğum Anabilim Dalı, Malatya

AMAÇ: Bu retrospektif çalışma akut apandisit ön tanısıyla apendektomi yapılan gebe ve gebe olmayan hastaların demografik ve klinikopatolojik özelliklerini karşıllaştırmayı amaçlamaktadır.

GEREÇ VE YÖNTEM: Haziran 2009 ve Ocak 2019 tarihleri arasında üreme çağındaki 43। kadın hastaya akut apandisit ön tanısıyla apendektomi yapıldı. Hastalar gebelik durumları gözönünde bulundurularak iki gruba ayrıldı: Gebe grup $(n=48)$ ve gebe olmayan grup $(n=383)$. Her iki grup demografik, klinik ve histopatolojik özellikler yönünden karşılaştırıldı.

BULGULAR: Gebe ve gebe olmayan gruplar arasında total bilirubin $(p=0.019)$ ve ultrasonografik bulgular $(p=0.016)$ dişında istatistiksel olarak anlamlı farklılık saptanmadı. Gebe olmayan grupta negatif apendektomi ve perforasyon oranları sırasıyla \% 26 ve \% 0.5 olarak hesaplanırken gebe grupta bu oranlar sırasıyla \%20.8 ve \%4.2 olarak hesaplandı. Ultrasonografinin gebe grubundaki sensistivite, spesifisite ve doğruluk oranları sırasıyla $\% 50, \% 100$ ve $\% 58.5$ olarak saptanırken gebe olmayan grupta bu oranlar sırasıla \%67.3, \%57.9 ve \%65 olarak bulundu. Gebelerin \%52.l'i birinci trimesterda, \%29.2'si ikinci trimesterda ve geriye kalan \%16.7'si üçüncü trimesterdaydı. Miadında gerçekleşen doğumların (\%87.5) hiçbirinde fetal veya maternal komplikasyon gelişmedi. Buna karşın preterm gerçekleşen doğumların (\%।2.5) ikisi neonatal mortalite ile sonuçlandı.

TARTIŞMA: İstatistiksel olarak anlamlılık göstermemekle birlikte gebelerde negatif apendektomi ve perfore akut apandisit oranları gebe olmayan hastalara göre daha düşük bulundu ki bu durumun en önemli sebebi akut karın ile başvuran gebelerin klinik olarak daha hassas bir şekilde değerlendirilmesidir.

Anahtar sözcükler: Akut apandisit; apendektomi; gebelik; obstetrik Komplikasyonlar; preterm eylem.

Ulus Travma Acil Cerrahi Derg 2020;26(4):555-562 doi: 10.14744/tjtes.2020. 12544 